W.P. 07-12

\title{
Forest management policies and resource balance in China: an assessment of the current situation
}

Sylvie Démurger, Hou Yuanzhao, Yang Weiyong

Avril 2007

GATE Groupe d'Analyse et de Théorie Économique UMR 5824 du CNRS

93 chemin des Mouilles - 69130 Écully - France

B.P. $167-69131$ Écully Cedex

Tél. +33 (0)4 72866060 - Fax +33 (0)4 72866090

Messagerie électronique gate@gate.cnrs.fr Serveur Web : www.gate.cnrs.fr 


\title{
Forest management policies and resource balance in China: an assessment of the current situation
}

\author{
Sylvie Démurger* \\ GATE, Université Lyon 2 - CNRS, France \\ demurger@gate.cnrs.fr \\ Hou Yuanzhao \\ Chinese Academy of Forestry, Beijing, China \\ houyuanzhao@163.net \\ Yang Weiyong \\ University of International Business \& Economics, Beijing, China \\ weiyongyang@gmail.com
}

This version: April 18, 2007

Corresponding author:

Sylvie Démurger

Groupe d'Analyse et de Théorie Economique (GATE), Université Lyon 2, CNRS

93, chemin des Mouilles

69131 Ecully Cedex - France

Tel: +33(0) 472866105

Fax: +33(0) 472866090

E-mail: demurger@gate.cnrs.fr

* A part of the research was conducted when Sylvie Démurger was visiting HIEBS at the University of Hong

Kong, whose hospitality is greatly acknowledged. 


\title{
Forest management policies and resource balance in China: an assessment of the current situation
}

\begin{abstract}
Using the latest forest inventory, this paper provides a comprehensive analysis of China's forest sector by focusing on new forest trends, forest policy changes and challenges to achieve a sustainable forest management. We analyze the dynamics of forest resources and provide an impact assessment of forest policies on China's forestry development over the last decades. Moreover, the analysis of the forest market highlights substantial disequilibria marked by a limited domestic supply potential and a growing demand for forest products satisfied by increasing imports. Internal and external solutions are explored and their implications for China and supplying countries are assessed.
\end{abstract}

Keywords: Forest management, Forest resources, Economic development, China. JEL classification: Q23, Q28, O13, O53

\section{Introduction}

Despite a forest cover of 175 million ha and a standing timber stock of 12.5 billion $\mathrm{m}^{3}$ that place the country respectively at the fifth and the seventh world rank, China can still be considered as forest-deficient. Its forest resources only account for $4 \%$ of world forests and less than $3 \%$ of world timber stock (FAO, 2003). Although China's forest coverage has recently increased up to $18.2 \%$, it still remains at half of the world average and China's forested area per capita of 0.13 ha is far below the world average of 0.65 . Timber stock comparisons highlight similar gaps since the standing stock volume amounts to less than $10 \mathrm{~m}^{3}$ per capita while the world average stands at approximately 66 .

The forest deficit that characterizes China is the outcome of a long history of deforestation, which particularly intensified after the founding of the People's Republic. Both the quantity and the quality of forest resources in China sharply decreased during the collectivization period (1958-82), 
notably during the Great leap forward and the Cultural Revolution ${ }^{1}$. The trend further accentuated at the beginning of the 1980s, insecure ownership rights leading farmers to clear forests after the household responsibility system was extended to forestlands.

At the same time, China's sustained economic growth has led to a surge in demand for forest products during the reform period, although per capita consumption of wood products is still low by international standards ${ }^{2}$. The construction boom including house building in both cities and rural areas, and the rising demand for educational and cultural activities have been important factors driving the sharp increase in demand and in quality requirements for wood materials, furniture, paper and paperboard. According to non-official estimates, the national timber consumption (excluding fuelwood) rose from 145 million $\mathrm{m}^{3}$ in 1993 to 283 million $\mathrm{m}^{3}$ in $2003^{3}$ (Zhu, 2004), with the paper sector being the largest wood consumer (32\% of the total), followed by construction and housing (22\%), rural energy consumption (21\%) and furniture (11\%) (Xiong 2004, Zhu 2004) ${ }^{4}$. With further increases in income, most of these uses are expected to rise in the future ${ }^{5}$.

Facing the ecological consequences of forest over-exploitation and the growing pressure from the demand side, the Chinese government has radically reoriented its forest policy over the last 20 years, by moving from a timber production strategy to resources and ecosystem conservation and restoration. These efforts helped China to successfully increase both its forest area and timber stock by the beginning of the 1990s (Table 1). Most recently, a new shift in forest policy has been taken

\footnotetext{
${ }^{1}$ Ignoring local natural conditions, these policies have led to large-scale deforestation, especially on slopping low-yielding land. From 1949 to 1979, the total harvest volume of timber exceeded one billon $\mathrm{m}^{3}$ (Wang et al., 2004). During the Great leap forward, thousands ha of forests have been logged to fuel backyard steel smelters and from the end of the 60s onwards, the conjunction of the self-sufficiency policy and the generalization of the Dazhai model led to the increase in cultivated land to the detriment of other land uses (Harkness, 1998 and Shapiro, 2001).

${ }^{2}$ China's current per capita timber consumption is only $0.12 \mathrm{~m}^{3}$, less than one-fifth of the world average $(0.68$ $\mathrm{m}^{3}$ ) (Zhou, 2001).

${ }^{3}$ There are no official data on timber consumption and estimations vary by sources. For 2003, FAOSTAT (2004) estimated China's total timber consumption at 247 million $\mathrm{m}^{3}$.

${ }^{4}$ Aggregate timber demand is even higher when fuelwood consumption is included. Bull and Nilsson (2004) highlight substantial data discrepancies on fuelwood consumption, which varies in a wide range from 3 million $\mathrm{m}^{3}$ to 252 million $\mathrm{m}^{3}$ according to sources. In 2003, domestic statistics indicated a total fuelwood consumption of 97 million $\mathrm{m}^{3}$, while FAO estimated total fuelwood removal at about 191 million $\mathrm{m}^{3}$ (Bull and Nilsson, 2004). ${ }^{5}$ It may be especially the case for the construction sector with China's interior decoration market being expected to grow at an annual rate of $20 \%$ in coming years (Sun et al., 2004b). China's demand for paper is also expected to continue to grow rapidly, especially for newsprint paper, printing and writing paper, containerboard and high quality boxboard. He and Barr (2004) forecast that given the rapid economic growth and increasing environmental concerns in recent years, the demand for wood pulp will rise from 9 million tons in 2003 to 15 million tons in 2010 .
} 
with the launching of Six National Key Forest Programs from the end of the 1990s, aiming at restoring, conserving, expanding and commercially developing China's forests, especially in ecologically sensitive areas such as Yangtze and Yellow Rivers' areas in the western region.

Although forest resources in China are expanding in both coverage and volume, constraints imposed by the new forest policy coupled with a continued growing demand for wood and structural domestic resource shortages have resulted in huge disequilibria in China's forest market. In recent years, the large gap between demand for and supply of wood has been mainly filled in by increasing imports $^{6}$, especially after tariffs on imports of logs were eliminated in 1999. China is now the major player in the international trade of many forest products such as logs, sawn wood and wood pulp for imports, and furniture for exports. China's total value of forest product imports ranks second in the world just after the US, and China ranks first in terms of industrial log imports. Moreover, the surge of Chinese imports is reported as causing severe ecological degradation and threatening the livelihood of local people in supplying countries, especially in the Asia-Pacific region where China is the dominant trade partner of many countries for forest products. Under these perspectives, any change in China's timber supply and demand may have important environmental, economic and social implications not only in China but also in the rest of the world.

The objective of this paper is to provide a comprehensive analysis of the Chinese forest sector along various dimensions covering forest resources and their recent evolution, changes in forest management patterns and in forest policy as well as the evolution of timber supply and its consequences on international forest markets. To this end, we use the latest forest inventory statistics released in 2005 for the period 1999-2003. To our knowledge, this paper is the first to use these statistics and as such, adds to the literature by providing an up-to-date assessment of recent forest policy changes.

The paper is organized as follows. First, we introduce changes in forest management patterns, with a special focus on the efficiency of both the forestry industrial sector and forest management. Next, we assess the impact of active forest policies implemented over the last two decades on China's

\footnotetext{
${ }^{6}$ As an example, the demand for wood pulp is mostly satisfied by imports, which filled in $62 \%$ of the nation's wood pulp demand in 2003 and $72 \%$ of the demand increase between 1990 and 2003.
} 
forest resources in terms of both quantity and quality. Finally, we discuss current and future challenges on both the domestic market and the international trade of forest products.

\section{Changes in forest management patterns: from exploitation to protection}

As briefly stated above, forest policies in China have undergone deep changes over the last twenty years. In this section, we review several major aspects of these policies before discussing their impact in the next section. Two main issues are worth emphasizing. First, management policies and forest tenure have changed markedly in both state-owned and collective forests, with however contrasted achievements between the two. On one hand, the State forest sector remains largely dominated by inefficient resources exploitation; on the other hand, the collective sector has turned to a privatized management, with a higher autonomy granted to households. Second, recent national largescale forest programs have marked a paradigm shift from forest resource exploitation to protection.

\subsection{Slow changes in the State forestry sector}

With the nationalization of natural forests in the early 1950s, two major institutions have been established to take on the management of state forests -state forest industry bureaus and state forest farms-. Their main objective was to supply cheap logs in support of national industrial development with little concern about forest protection and resource over-exploitation.

On one hand, 136 state forest industry bureaus, mostly located in northeast, northwest and southwest provinces control 28.7 million ha of forest (16.8\% of total forest area) with a standing timber stock of 3.17 billion $\mathrm{m}^{3}$ (23.9\% of the national total). Established for timber production and transformation as well as for forest management, these bureaus operate as state-owned enterprises under the control of central and provincial governments. On the other hand, 4,190 registered state forest farms devoted to afforestation purposes manage 31.8 million ha of forests (19\% of Chinese forest resources) (SFA, 2004a). They are more widely distributed throughout the country, despite a high concentration in the South. Most of these farms are under the auspices of local governments and 
run by managers appointed by the government at different levels from provincial to county government.

In the early reform period, problems similar to other State-owned industrial sectors in China were underpinning the whole inefficiency of the State forestry sector. To tackle problems of monoproduction, low productivity, overstaffing, and lack of incentives, the government has taken a number of measures, including timber price increase ${ }^{7}$, the implementation of a so-called "multipleexploitation" policy in 1984 to promote diversification and integration in the sector, and the introduction of the responsibility system providing greater autonomy in enterprise's management, with income being more closely related to enterprise's performance. Moreover, in the 1990s, sales by auction, leases under contract and transformations into shareholding enterprises have been introduced to improve the overall efficiency of the State forest sector.

Despite these efforts, the forestry sector still operates to a large extent under the planning system with production quotas ${ }^{8}$ and suffers from an overall inefficient management that induces forest resources waste and to some extent exhaustion. Moreover, the "multiple-exploitation" scheme only plays a limited role in income diversification since timber products still represent more than two-third of State forest enterprises total income (SFA, 2004a). The implementation of the Natural Forest Protection Program (NFPP) since 1998 has further worsened the situation because of dramatic reductions in timber production and employment. As a result, the financial situation of the state forestry industry continued to deteriorate and the amount of non-paid salaries and pensions has risen steadily since the mid-1990s. In 2003, the whole state forest industry was running a net deficit of 460 million yuan. The same year, unpaid salaries and pensions amounted to 1.6 billion yuan and concerned 570,000 workers.

\footnotetext{
${ }^{7}$ In 1979, State procurement prices of timber have been increased by $30 \%$ on average, and in 1990, the State Council raised the prices by $48 \%, 27.6 \%$ and 53\% respectively for timber, sawn wood and veneer produced by State forest farms in northeast and in Inner Mongolia (SFA, 1990a).

${ }^{8}$ In 1985, an annual harvest quota system was introduced to regulate timber production. Since 1990 quotas have been positively linked to each region's annual afforestation or reforestation area.
} 


\subsection{Management patterns in collective forests: from communities to households}

Compared with state forests, tenure and management systems for collective forests have experienced deeper changes over time and across regions (Liu, 2001), with the emergence of private ownership on trees over the reform period ${ }^{9}$. The turning point for collective forests management has been the forest policy issued in 1981, which consisted of three major components: (1) the stabilization of forest tenure through property certificates provided to owners, (2) the distribution of non-forested land to rural households as family plots, and (3) the introduction of the Contract Responsibility System. The national implementation of this policy has resulted in a variety of management patterns from collective management ${ }^{10}$ to household-based tenure.

At the household level, family plots and responsibility lands are the two main forms of forest tenure. Property rights and usufruct rights on forestland are separated, and private property and inheritance rights on trees planted by households are guaranteed ${ }^{11}$. By the end of 1984, a total area of 31.3 million ha had been distributed to 57 million households (SFA, 1986a). Most plots distributed to households were wastelands and degraded or fragmented forestlands and tree planting was intended to cover individual needs for fuelwood and timber. Moreover, as in agriculture, a large portion of the existing collective forests has also been contracted to households under the responsibility system in the early 1980s. Forests under this system remained collectively owned, but management rights were transferred to households. In the following years, some of these plots were merged with family plots and some taken back from households by local collectivities, but the majority remained under the responsibility system (Liu, 2001).

In the 1990s, several new tenure forms have emerged to further improve forest management and foster afforestation. In 1992, the Wastelands Auction policy encouraged local authorities to auction off their wastelands to households for reforestation under a 30 to 100 years lease contract.

\footnotetext{
${ }^{9}$ Regarding ownership issues, land ownership and trees ownership are to be distinguished in China. In terms of land ownership, the Law states that forest resources shall belong to the State unless it stipulates they belong to collectivities.

${ }^{10}$ Non-distributed collective forests are placed under the management of collective forest farms (Zhang et al., 1999), with township and village forest farms and joint-forest farms being the dominant management forms for community forestry.

${ }^{11}$ Property rights on planted trees introduced under the "who plants, who owns" principle in the early 1980s have been officially recognized within the revised Forest Law of China in 1998. Those "private forests" were previously referred as "collective forests" because land remains collectively owned.
} 
Property rights for these lands are similar to family plots (Miao and West, 2004). As a result, the role played by households in collective forest management has increased rapidly. According to Hyde et al. (2003), approximately $80 \%$ of collective forests are now under individual household management. At the same time, household-based management patterns further diversified with the emergence of various self-initiated shareholding systems, aimed at solving problems related to land fragmentation and high family exploitation costs of small forest plots ${ }^{12}$.

\subsection{New forest policies: a shift from resource exploitation to resource protection}

A growing concern about the necessity for environmental protection and forests conservation has led to several major policy changes since the mid-1990s. Hence, the shift of government priorities towards ecosystem restoration has resulted in a shift in forest management strategies through the adoption of a new forest classification policy and the implementation of several major forest programs.

In 1995, a new forest classification framework has been introduced for experimentation in more than 40 counties, and then endorsed officially by the revised Forest Law in 1998 (SFA, 1998a). Under this new policy, the 5 categories of forests identified by the 1984 Forest Law have been reclassified into two categories: ecological forests (consisting of former shelter forests and forests for special use), and commercial forests (comprising former timber forests, economic forests, and fuelwood forests). Regulations on management, funding and exploitation are different for these two categories of forests. Commercial forests basically follow market rules, while ecological forests remain mostly funded by the government, and to a lesser extent, by social participation and beneficiary's compensation.

The rising importance of ecological concerns has been further consolidated by the implementation of several wide-scale programs newly created or restructured from existing programs to both protect forest resources and promote forestry development within the Six National Key Forest Programs approved by the State Council in 2000. The new strategy is meant to be more integrated in the sense that it is designed to promote both protection of existing threatened forest resources and

\footnotetext{
${ }^{12}$ The shareholding system can take various forms including farmer-farmer collaboration, company-community partnership or cooperation with outside individuals and communities (Liu, 2001).
} 
production through timber forests plantations. The six programs include the Natural Forest Protection Program (NFPP), the Sloping Land Conversion Program (SLCP), the Desertification and Dust Storms Control Program in the vicinity of Beijing and Tianjin Municipalities, the Forest Shelterbelt Development Program in key environmentally fragile regions, the Wildlife Conservation and Nature Reserves Development Program, and the Fast-growing and High-yield Timber Plantations Program (FGHY). During the 1998-2003 period, the six programs have been financed mainly by State investments ${ }^{13}$, which accounted for $83.5 \%$ of a total of 94.67 billion yuan (SFA, 2004a).

The government's new concerns about ecosystem restoration are particularly embodied into two of these national programs, the Natural Forest Protection Program and the Sloping Land Conversion Program. First implemented in pilot areas in 1998 and then extended in 2000 for a period of 11 years, the Natural Forest Protection Program aimed at reducing the annual timber production, which actually dropped from 64 million $\mathrm{m}^{3}$ in 1997 to 44 million $\mathrm{m}^{3}$ in 2002 (SFA, 2004b). The three main components of the program are a logging ban (or reduction) in state-owned natural forests in 17 provinces along the Yangtze and the Yellow Rivers or in sensitive areas ${ }^{14}$, the afforestation of barren land and mountains, and the restructuring of the State-owned forestry industry ${ }^{15}$. More than one fifth of total forested land in China (30 million ha of natural forests) is affected by the logging ban. The strict implementation of the logging ban has however been progressively relaxed from 2000, in order to limit the negative impact of the program on local populations. Hence, restrictions are maintained or even reinforced for ecological forests while several logging activities have been allowed in commercial forests to take into account both wood products needs and ecological conditions. As a result, the national timber production quota has increased again up to 52 million $\mathrm{m}^{3}$ in 2004 (SFA, 2004b).

\footnotetext{
${ }^{13}$ The only exception is the market-oriented program of fast-growing and high-yield plantations, mostly financed by farmers, forest farms and foreign capital. The state investment only had a marginal portion, $6.6 \%$ of the total investment for the period 1998-2003 (SFA, 2004c).

${ }^{14}$ The logging ban is implemented in provinces of the middle and upper reaches of the Yangtze (Tibet, Yunnan, Sichuan, Chongqing, Guizhou, Hubei) and the Yellow river (Qinghai, Gansu, Ningxia, Inner Mongolia, Sha'anxi, Shanxi, Henan). The logging reduction in state-owned forests also concerns Northeast provinces (Jilin and Heilongjiang) as well as Hainan and Xinjiang.

${ }^{15}$ This third component is mainly of a "social" nature and aims at facilitating the re-employment of redundant workers from State-owned forest enterprises as well as pensions payment. By 2003 , more than $80 \%$ of the 740,000 workers made redundant by the program had been re-employed in forestry or other economic sectors (SFA, 2004c).
} 
Launched in 1999 in three pilot provinces (Gansu, Sha'anxi and Sichuan) and progressively extended to 25 provinces (Xu et al., 2004), the Sloping Land Conversion Program aims at reducing soil erosion by converting more than 14 million ha of cultivated land into forests and grassland ${ }^{16}$. After its full-scale implementation in 2001, the conversion program has been the main driving force of afforestation increase in China. For example, 68\% of the record 9 million ha of total annual afforestation in 2003 came from afforestation achieved under the program that year.

\section{The "forest deficit": achievements and constraints}

Since the first national forest inventory (1973-1976), China's forest resources have increased both in area and in standing stock volume, rising from 121.9 million ha and 9.5 billion $\mathrm{m}^{3}$ to respectively 171.1 million ha and 12.5 billion $\mathrm{m}^{3}$ in the sixth inventory (1999-2003) (Table 1). According to the latest inventory, the annual growth of timber stock has been 496.7 million $\mathrm{m}^{3}$ over the period 1999-2003, whereas forest depletion is estimated to be about 365.4 million $\mathrm{m}^{3}$ per year, therefore implying a net annual increase of 131.4 million $\mathrm{m}^{3}$.

Although part of these upward trends may be attributed to repeated changes in the definition of forest area over the whole period ${ }^{17}$, they also suggest an improving overall situation for forest resources in China. As highlighted above, the seemingly reducing forest deficit can be related to various changes in forest management and policies, which have promoted a "privatization" process on trees ownership, as well as the reorientation of policies towards both forest resources protection and afforestation. To further discuss their impact on China's forest resources and wood market, this section uses new forest inventory statistics to evaluate the major achievements as well as the remaining constraints.

\footnotetext{
${ }^{16}$ The conversion program also includes tree planting on barren land and mountains.

${ }^{17}$ The canopy cover requirement to define forests has been relaxed progressively from $40 \%$ in the mid-1980s to $20 \%$ at the end of the 1990s. During the sixth forest inventory, the definition of forests has been further extended to include shrubs. This change is estimated to have contributed to an increase of 0.39 percentage point in forest cover between the fifth and sixth inventory. Hence, $24 \%$ of the forest cover increase would come from this definition change.
} 


\subsection{Major achievements}

As discussed above, the major changes in China's forestry sector over the recent years can be found in the greater role given to the private sector as well as in the greater emphasis put on both afforestation and resources conservation. The effectiveness of these changes can be assessed through the evolution of forest resources, the changes in forest removal trends as well as the relative importance of various forest categories.

Table 2 shows the distribution of forest resources by categories of ownership over trees ${ }^{18}$ : state-owned forests, collective-owned forests and private forests. The changing ownership structure of forest resources clearly highlights the changing role of the private sector. The new tenure forms have attracted investment into forestry activities, and private participation in forestry development has risen steadily since the late 1990s. Hence, although state forests still account for the largest shares in both forested area and stock volume, China had 35.1 million ha of private forests by the end of 2003, which accounted for $20.3 \%$ of total forest area and $6.8 \%$ of total forest standing volume. Private ownership is particularly widespread in economic forests, with more than $60 \%$ of non-timber trees belonging to households and other private owners. Moreover, the rise of private forests should strengthen in the future because private ownership was accounting for $41 \%$ of pre-forest plantations in 2003 and $80 \%$ of annual new plantations in 2003-2004.

A key direction to reduce pressure upon natural forests and increase the overall timber supply has been to develop a domestic forest base through timber plantations. With a total 53 million ha of plantation forests, China is the world leading country in tree plantations. As highlighted above, these activities have been undertaken both by the government and the private sector within various largescale programs. Within the Sloping Land Conversion Program, 7.05 million ha of cultivated land had been converted and 8.79 million ha of wastelands afforested by the end of $2004^{19}$, and within the Fastgrowing and High-yielding Timber Plantations Program, 1.75 million ha had been planted by 2003

\footnotetext{
${ }^{18}$ Previous forest inventories only provided a classification according to the ownership of forest land, that is State or collective forests.

${ }^{19}$ Most plantations are ecological forests, which account for $79 \%$ of the total afforested area (SFA, 2004b).
} 
$(\mathrm{SFA}, 2004 \mathrm{~b})^{20}$. As a result of all these efforts, data from the latest forest inventory indicate that manmade forests now account for $33 \%$ of total forest area, which represents a 6.8 million ha (or $13.4 \%$ ) increase from the fifth inventory.

In terms of forest removal, one of the main characteristics of China's forest resources crisis highlighted by Yin (1998) at the end of the 1990s was the rapid depletion of natural forests. Since then, the implementation of the Natural Forest Protection Program has contributed to changing patterns, with opposite harvesting trends between natural and man-made forests on one hand, and between state and collective forests on the other hand. To satisfy the growing timber demand, China has indeed promoted timber supply from man-made forests and from non-program areas. Therefore, during the 1999-2003 period, annual harvest from natural forests has been reduced by 24 million $\mathrm{m}^{3}$ while annual harvest from man-made forests increased by 19 million $\mathrm{m}^{3}$ as compared to the 19941998 period. During the same period, timber harvest in program areas decreased by 36.6 million $\mathrm{m}^{3}$ per year on average, mostly compensated by an annual increase of 31.2 million $\mathrm{m}^{3}$ harvested in nonprogram areas, especially from man-made forests outside program areas $\left(20\right.$ million $\left.\mathrm{m}^{3}\right)$. Similarly, timber harvests from state-owned forests have decreased while the share of timber production from collectively-owned man-made forests increased. Hence, during the 1999-2003 period, the average forest removal from state forests was 153.1 million $\mathrm{m}^{3}$ per year, a reduction of 21.6 million $\mathrm{m}^{3}$ as compared to the 1994-1998 period. At the same time, the annual removal from the Southern region increased by 10 million $\mathrm{m}^{3}$ to reach 157.5 million $\mathrm{m}^{3}$.

Last, changes in forest managements have led to some important structural changes in terms of forest categories. Almost half of existing forests are timber forests, one third are protection forests, and the remaining are economic forests, fuelwood forests and forests for special use. Figure 1 shows that the structural evolution has been marked by a substantial decline of timber forests and fuelwood forests as well as by a significant rise of ecological forests ${ }^{21}$. This structural change is particularly obvious from the fifth (1994-1998) to the sixth inventory (1999-2003), during which the share of

\footnotetext{
${ }^{20}$ This program has been especially designed to promote the development of industrial tree plantations. Its objective is to increase the domestic commercial wood supply by subsidizing the plantation of 13.3 million ha of trees over the period 2001-2015 (Barr and Cossalter, 2004).

${ }^{21}$ Ecological forests include protection forests and forests for special use.
} 
ecological forests has increased from $17 \%$ to $38 \%$ of total forest area as a result of the new orientation of China's policy from forestry production to resource conservation and ecological safety reinforcement.

The trend may be strengthened in the future because ecological forests also account for more than $75 \%$ of the total annual afforestation since 2002 (Figure 2). Over the recent years, substantial changes in the afforestation structure have actually occurred. At the beginning of the 1990s, timber forests were predominant with a share of $60 \%$ of total plantings, followed by ecological forests (23\%) and economic forests (12\%). However, during the 1990s, timber forests have gradually lost importance in favor of economic forests ${ }^{22}$ and, more importantly, ecological forests. Since the late 1990s, the share of ecological forests in afforestation has risen sharply from $32 \%$ in 1997 to $75 \%$ in 2004, at the expense of both timber forests and economic forests. Hence, with the timber forest share in annual afforestation continuously falling from $34 \%$ in 1997 to $16 \%$ in 2004 , the dramatic changes in afforestation structure since 1998 can be expected to further constrain wood supply perspectives in the future.

\section{2. $\quad$ A still limited wood supply}

Despite non-negligible achievements, China's domestic wood supply capacity remains limited. The shortage of total available forest resources, the still inappropriate age structure and the low quality of Chinese forests all indicate that China's forest resources crisis may still be acute.

As discussed above, adjustments on forest types made under the new forestry policy have reduced the area of designated timber forests. Hence, due to increased restrictions, timber forest resources have decreased by 19.5 million ha and 1.3 billion $\mathrm{m}^{3}$ between the fifth and sixth inventories. Available forests for timber production now amount to only 8.9 million ha with a total stock volume

\footnotetext{
${ }^{22}$ This evolution can be explained on one hand, by the relative short production cycle of economic forests compared with timber forests, and on the other hand, by policy uncertainty, property rights insecurity, heavy taxes, and harvest and transport restrictions associated with timber forests (Liu, 2001; Miao and West, 2004).
} 
of 1.28 billion $\mathrm{m}^{3}$, which represents respectively $6.2 \%$ of the total closed forest area and $10.6 \%$ of total forest stock $^{23}$.

To satisfy the growing timber demand over the reform period, domestic supply has increased rapidly at the expense of the country's forest resources. China's timber production consists in three components: $i$ ) planned production according to the State harvest quota, $i$ i) non-reported above quota production, and iii) non-commercialized production for self-consumption in rural areas. Since the introduction of the harvest quota system in 1987, above quota production is prevalent throughout the country, but Chinese official statistics on timber production only report the planned production (Table 3), and thus systematically under-evaluate the true production level. According to estimates from the State Forestry Administration, even during the period of the sixth forest inventory (1998-2003), which coincides with the implementation of the Natural Forest Protection Program, the average above quota harvest was 75.54 million $\mathrm{m}^{3}$ per year, compared with an average quota production of 47.42 million $\mathrm{m}^{324}$

The high level of above quota production coupled with illegal logging significantly reduces the effectiveness of forest protection programs. Despite the reduction in production quotas and the shift in harvest from natural forests to man-mad forests since 1998, natural forests continue to be depleted. During the period of the sixth forest inventory, the annual removal from natural closed forests was 266.1 million $\mathrm{m}^{3}$, which still accounted for $72.8 \%$ of total forest removal. Moreover, China is prematurely harvesting its young and middle-aged forests mainly because almost $70 \%$ of available timber forests are located in six provinces at the core of the Natural Forest Protection Program (Heilongjiang, Jilin, Inner Mongolia, Sichuan, Shaanxi and Tibet). Table 4 shows that $56.4 \%$ of total forest depletion comes from young and middle-aged forests, in contrast with $26.7 \%$ from

\footnotetext{
${ }^{23}$ Because of accessibility issues, another 2.4 million ha and 470.9 million $\mathrm{m}^{3}$ of near-mature, mature and overmature forests are not available for wood supply. On the other hand, available resources increase to 18.9 million ha with a stock volume of 2.2 billion $\mathrm{m}^{3}$ when including forests at near-mature age.

${ }^{24}$ China's actual timber production in 2003 has been estimated at 160 million $\mathrm{m}^{3}$, three times the quota production (Zhu 2004). Depending on the conversion factor used to convert timber production into log removal from forests (Chinamarket Consulting Company 2004, Xiong 2004), forest removal for timber production in 2003 ranges from 246 to 278 million $\mathrm{m}^{3}$, slightly higher than the estimation proposed in the sixth forest inventory (238.9 million $\mathrm{m}^{3}$ ). With an additional official estimates of 97 million $\mathrm{m}^{3}$ for fuelwood, the total forest removal for 2003 ranges between 343 and 375 million $\mathrm{m}^{3}$, which is also consistent with the 365 million $\mathrm{m}^{3}$ of annual forest depletion estimated by the sixth forest inventory.
} 
mature and over-mature forests, reflecting both the scarcity and the limited accessibility of mature forests. The depletion of middle-aged forests is particularly important, accounting for $37.8 \%$ of total natural forest depletion and $45.6 \%$ of total man-made forest depletion.

Two additional indicators of the still acute forest crisis in China are the unfavorable age structure and the low productivity of Chinese forests. Hence, the sixth forest inventory confirms the predominance of young and middle-aged forests (68\% of forest area) and the scarcity or lowaccessibility of mature and over-mature forests. In dynamic terms, the comparison of various national forest inventories shows interesting changes in the forest age structure since the mid-1980s (Figure 3). On the one hand, both the area and the stock of young forests have decreased in relative importance in favor of middle-aged and near-mature forests since the mid-1990s, which entails a potential increase in available forest resources in a near future. On the other hand, the share of mature and over-mature forests is also declining since the end of the 1980s, which exacerbates current resource shortages. In particular, between the last two forest inventories, mature and over-mature timber forests have decreased by 3 million ha with a net drop of 73 million $\mathrm{m}^{3}$ in timber stock. Finally, the low quality of Chinese forests is reflected in the low level of the average stock volume $\left(84.73 \mathrm{~m}^{3}\right.$ per ha). Although this level has continuously increased over time (from $75 \mathrm{~m}^{3}$ per ha in the fourth forest inventory), it remains far below the world average $\left(99.85 \mathrm{~m}^{3}\right.$ per ha). The productivity of both man-made forests and collective forests is even lower with respectively 47 and $44 \mathrm{~m}^{3}$ per ha.

\section{The import response to a limited supply}

China's growing demand for wood coupled with a limited supply has resulted in a dramatic surge in imports for all forest products including unprocessed logs, sawn wood, wood chips, fiberboard, particleboard, veneer, paper and paper pulp ${ }^{25}$. Figure 4 shows that since the implementation of the Natural Forest Protection Program, imports of logs and sawn wood have

\footnotetext{
${ }^{25}$ The import growth also resulted from preferential trade policies for forest products. By 1999, import permit requirements for wood products have been abolished, and any company legally registered for international trade is allowed to import wood products (Sun et al., 2004b). Meanwhile, import tariff rates for forest products have been substantially reduced, down to zero for log import. In August 2004, China also reduced by $50 \%$ the valueadded tax on logs imported through border trade, especially for logs from Russia (Katsigris et al., 2004).
} 
increased massively ${ }^{26}$. Recent trends also highlight a shift from high value-added imports (such as plywood, veneer, fiberboard and paper) to unprocessed forest products such as log, sawn wood and wood pulp. Higher value-added imports made up almost half of China's timber product imports in 1997, but by 2003 logs and sawn wood constituted 78\% of total timber product import value (Sun $e t$ al., 2004a). This trend reflects China's strategy to develop its competitive labor-intensive wood processing industry with imported raw materials in order to export higher value-added forest products such as furniture, paper products and plywood ${ }^{27}$.

China imports forest products from a number of forest-rich countries, including Russia, Malaysia, Indonesia, New Zealand, Thailand, the US, Gabon, Papua New Guinea, Germany, Myanmar, Cambodia, and Laos. Table 5 lists China's main trading partners by forest products and shows the dominant role of Asia-Pacific countries in Chinese imports. Given the large volume of its imports, China has also become the dominant forest trade partner for many Asia-Pacific supplying countries. By 2002, China accounted for over $40 \%$ of total log exports in Russia, Malaysia and Indonesia. This share was even higher in some small countries of the region such as Papua New Guinea (64\%), Myanmar (69\%) and Thailand (81\%) (Katsigris et al., 2004).

Since 1997, Russia, Malaysia and Indonesia have been the three leading suppliers, contributing to more than 50\% of China's total timber products import every year between 1997 and $2003^{28}$. Russia is by far China's top timber product supplier both in volume and in value, with an import volume to China of about 15.3 million $\mathrm{m}^{3}$ (round wood equivalent) in 2003, representing $12 \%$ of China's total imports (SFA, 2004a). In addition, a large number of Chinese firms have crossed the border to set up wood harvest or processing mills, using essentially Chinese labor in Russia's Far East region.

In the Asia Pacific region where forest products exports are dominated by the Chinese market, the sharp increase in China's demand for forest products, logs in particular, has had deep negative effects on local ecological systems and on the livelihood of local communities and population. Indeed,

\footnotetext{
${ }^{26}$ The most significant increase comes from pulp and paper that currently account for about $60 \%$ of China's forest product imports by Round-wood-equivalent volume (Sun et al., 2004a).

${ }^{27}$ Chinese exports of forest products account for almost $10 \%$ of China's total wood consumption.

${ }^{28}$ In 2003, China's combined timber product imports from the three countries totaled approximately 23.6 million $\mathrm{m}^{3}$ (round wood equivalent) valued at US $\$ 2.2$ billion.
} 
massive deforestation and biodiversity loss can be observed in many supplying countries because of unsustainable practices and illegal loggings. According to Katsigris et al. (2004), the natural forests of Papua New Guinea and Myanmar will be completely exhausted within 10 to 15 years if current logging rates are maintained. Furthermore, deforestation and illegal loggings induced by the surge in China's wood demand have caused numerous economic and social problems, including government corruption and tax revenues losses in Russia and in Papua New Guinea, as well as loss of access to resources by forest-dependent people and inequality in the distribution of logging trade benefits in Thailand, Laos, Cambodia and Myanmar (Katsigris et al., 2004; Barney, 2005).

Decreasing forest resources and increasing local social resistance within supplying countries may create serious problems to Chinese imports of forest products in the future. Analyzing the future supply conditions in the Asia-Pacific supplying countries, Katsigris et al. (2004) concluded that the supply possibilities will decrease in a majority of these countries within the next 10 to 15 years. Only Russia presents a high potential of log supply for China with its vast forest area (about 280 million ha) in the Far East region. Import perspectives are even less encouraging since the aggressive strategy to develop domestic wood processing industries in countries such as Indonesia and Russia may further reduce log availability for export to China.

\section{Strategies for sustainable forest management}

During the reform period, China's forest resources have increased in both area and stock volume. This encouraging trend is the result of both afforestation activities and increasing efforts made by the government to protect forests with the implementation of large-scale national programs focusing on natural forest protection and plantation development. Despite its positive impact on China's forest resources, the recent shift of forest policies from resource exploitation to resource protection also contributes to a further reduction of domestic timber supply potential, already tightly constrained by historical over-harvesting and by the low productivity and inappropriate age structure of existing forests. Simultaneously, the rapid wood demand increase driven by industrial needs in the construction, paper and furniture sectors, as well as by high fuelwood consumption in rural areas 
undoubtedly put heavy pressure on domestic timber supply. As a result, the continuing excess demand for wood is being more and more satisfied by imports as illustrated by the dramatic increase in China's import of forest products in recent years, which is seen as imposing severe pressures on the utilization of forest resources in countries surrounding China as well as in other parts of the world.

Although the demand for fuelwood may eventually decrease as rural households' income increases (Chen et al. 2006; Démurger and Fournier 2006), the demand for wood products can be reasonably expected to increase further at a sustained rate as the country develops, since the demand for specific products such as paper or furniture is income elastic. Given the conjectured growing demand for timber, the estimated gap between consumption and domestically produced forest products in China, currently above 100 million $\mathrm{m}^{3}$ (in RWE), may reasonably be expected to increase further in the future. China therefore needs to take active measures to achieve the two competing objectives of protecting its natural forests for environmental consideration while satisfying its expanding demand for wood products.

\subsection{Reinforcing national programs and their local implementation}

The achievement of long-term ecological objectives is critical to China's sustainable development. Therefore, the government's efforts to protect forest resources through national programs should be reinforced. However one of the main drawbacks of these centrally designed programs is that they do not always fit local natural, economic and social conditions (Démurger et al. 2005). In order to improve their effectiveness, a better policy design is needed with a more integrated and participative approach at the local level.

\section{2. $\quad$ Securing property rights}

To encourage plantation activities and to attract investments in these activities, it is also necessary to promote innovative management forms such as shareholding systems and forest privatization. The prerequisite for a sound management is to stabilize forest policies and to secure ownership rights on planted trees. Although efforts have been done towards securing property rights to farmers, evidence shows that tenure insecurity remains a major problem in rural China (Xu et al., 
2002). In this context, farmers are reluctant to invest in long-term forest-related activities, which may still prove more risky and less efficient than other non-agricultural activities in a process of income sources diversification and insurance against agricultural risks (Démurger and Yang, 2006).

\subsection{Ensuring sustained plantation}

In order to meet the growing demand for wood, greater efforts are needed to promote and ensure the continuing development of fast-growing and high-yielding plantations. All agents, particularly in the private sector, should be encouraged to invest in forest plantation. Moreover, downstream industries such as paper and pulp industry may develop their own resource bases by establishing fast-growing and high-yielding plantations. Although it is mainly a private and markedoriented business, governments and research organizations can still play an important role by promoting high-quality species with high-yield and high commercial value on one side, and providing financial and fiscal advantages such as low-interest loan and tax delay on the other side.

\subsection{Developing long-term relationship with partners}

Last, to secure imports of forest products, China also needs to develop long-term relationships with supplying countries, Russia in particular. This requires China's commitment to promote sustainable harvest patterns and increase investments in plantation activities in these countries. In this respect, effectively enforced cooperation schemes with neighboring countries could help reducing illegal logging and timber smuggling. 


\section{References}

Barney, K., 2005. "Customs, concessionaries and conflicts: Tracking Cambodia's forest commodity chains and export links with China", Forest Trends, http://www.foresttrends.org/documents/publications/Cambodia\%20Report_final_8-22-05.pdf.

Barr, C., Cossalter C., 2004. "China's development of a plantation-based wood pulp industry: government policies, financial incentives, and investment trends", International Forestry Review, 6(3-4), pp. 267-281.

Bull, G.Q., Nilsson, S., 2004. “An Assessment of China's Forest Resources”, International Forestry Review, 6(3-4), pp. 210-220.

Chen, L., Heerink, N., van den Berg, M., 2006. "Energy consumption in rural China: A household model for three villages in Jiangxi Province", Ecological Economics, 58(2), 407-420.

Chinamarket Consulting Company, 2004. China Wood Market Report, May.

Démurger, S., Fournier, M., 2006. "Rural poverty and fuelwood consumption: Evidence from Labagoumen Township (China)", mimeo.

Démurger, S., Fournier, M., Shen, G., 2005. "Forest Protection Policies: National Guidelines and Their Local Implication in Northern Sichuan”, China Perspectives, No. 59, May-June, pp. 1-12.

Démurger, S., Yang, W., 2006. "Economic changes and afforestation incentives in rural China", Environment and Development Economics, Vol. 11, No. 5, October 2006, pp. 629-649.

Food and Agriculture Organization, 2003. The State of the World's Forests 2003, Rome: FAO.

FAOSTAT data 2004. FAO, Rome, Italy.

Harkness, J., 1998. "Recent Trends in Forestry and Conservation of Biodiversity in China", The China Quarterly, No. 156, December, pp. 911-934.

He, D., Barr, C., 2004. "China's Pulp and Paper Sector: An Analysis of Supply-Demand and Medium Term Projections", International Forestry Review, 6(3-4), pp. 254-266.

Hyde, W. F., Belcher, B., Xu, J., 2003. China's Forests: Global Lessons from Market Reforms, Washington D.C.: Resources for the Future Press.

Katsigris, E., Bull, G.Q., White, A., Barr, C., Barnez, K., Bun, Y., Kahrl, F., King, T., Lankin, A., Lebedev, A. Shearman, P., Sheingauz, A., Su, Y., Weyerhaeuser, H., 2004. "The China Forest Products Trade: Overview of Asia-Pacific Supplying Countries, Impacts and Implications", International Forestry Review, 6(3-4), pp. 237-253.

Liu, D., 2001. "Tenure and Management of Non-State Forests in China since 1950: A Historical Review”, Environmental History, vol. 6 (2), April, pp. 239-263. 
Miao, G., West, R. A., 2004. "Chinese collective forestlands: contributions and constraints", International Forestry Review, 6(3-4), pp.282-298.

Shapiro, J., 2001. Mao's war against nature: Politics and the Environment in Revolutionary China, Cambridge University Press.

State Forestry Administration, 2000. Forest Resources Statistics of China, 1994-1998, Beijing: State Forestry Administration.

State Forestry Administration (SFA), 1986a-2004a. China Forestry Yearbook, Beijing: China forestry publishing house.

State Forestry Administration (SFA), 1987b-2004b. China Forestry Statistical Yearbook, Beijing: China forestry publishing house.

State Forestry Administration (SFA), 2004c. China Forestry Development Report, Beijing: China forestry publishing house.

Sun, X., Katsigris, E., White, A., 2004a. "Meeting China's Demand for Forest Products: An Overview of Import Trends, Ports of Entry, and Supplying Countries, with Emphasis on the Asia-Pacific Region”, International Forestry Review, Vol. 6 (3-4), pp. 227-236.

Sun, X., Wang, L., Gu, Z., 2004b. "A Brief Overview of China's Timber Market Sytem”, International Forestry Review, Vol. 6 (3-4), pp. 221-226.

Wang, S., van Kooten, G. C., Wilson, B., 2004. "Mosaic of reform: forest policy in post-1978 China", Forest Policy and Economics, 6(1), January, 71-83.

Xiong, M. (2004), A Study on the Relationship between Wood Industry and Sustainable Forestry Development in China, Master Degree Dissertation, Chinese Academy of Forestry, Beijing.

$\mathrm{Xu}$, J., Katsigris, E. White, T. A., 2002. Implementing the Natural Forest Protection Program and the Sloping Land Conversion Program: Lessons and Policy Recommendations. China Council for International Cooperation on Environment and Development (CCICED) Task Force on Forests and Grasslands, Beijing: China Forestry Publishing Housing.

Xu Z., Bennett, M. T., Tao, R., Xu, J., 2004. “China’s Sloping Land Conversion Program four years on: current situation, pending issues", International Forestry Review, Vol. 6, No. 3-4, December, pp. 317-326.

Yin, R., 1998. "Forestry and the Environment in China: the Current Situation and Strategic Choices", World development, 26(12), 2153-2167. 
Zhang, Y., Dai, G., Huang, H., Kong, F., Tian, Z., Wang, X., Zhang, L., 1999. “The Forest Sector in China: Towards a Market Economy", in M. Palo and J. Uusivuori eds., World Forests, Society and Environment, Dordrecht: Kluwer Academic Publishers.

Zhou, S., 2001. "Global Ecological Crisis and Rapid Development of Chinese forestry" (Quanqiu shengtai weiji yu zhongguo linye kuayueshi fazhan), China Forestry (in Chinese), June.

Zhu, G., 2004. "Evolutions and Trends of China's timber and forest products imports" (Zhongguo mucai ji linchanpin jinchukou taishi ji zouxiang), Paper Collection of the High Level Forum on the Sustainable Development of Chinese Timber Industry (Zhongguo mucai gongye kechixu fazhan gaoceng luntan lunwenji), pp. 11-36. 
Table 1 - Change in China's regional distribution of forest resources

\begin{tabular}{|c|c|c|c|c|c|c|c|c|c|c|c|}
\hline \multirow{3}{*}{ National } & \multirow[b]{3}{*}{ Forested area } & \multicolumn{2}{|c|}{$\begin{array}{c}2^{\text {nd }} \text { inventory: } \\
1977-1981\end{array}$} & \multicolumn{2}{|c|}{$\begin{array}{c}3^{\text {rd }} \text { inventory: } \\
\text { 1984-1988 }\end{array}$} & \multicolumn{2}{|c|}{$\begin{array}{c}4^{\text {th }} \text { inventory: } \\
1989-1993\end{array}$} & \multicolumn{2}{|c|}{$\begin{array}{c}5^{\text {th }} \text { inventory: } \\
1994-1998\end{array}$} & \multicolumn{2}{|c|}{$\begin{array}{c}6^{\text {th }} \text { inventory: } \\
1999-2003\end{array}$} \\
\hline & & \multicolumn{2}{|r|}{$\%$} & \multicolumn{2}{|r|}{$\%$} & \multicolumn{2}{|c|}{$\%$} & \multicolumn{2}{|c|}{$\%$} & \multicolumn{2}{|c|}{$\%$} \\
\hline & & 115.3 & 100 & 124.7 & 100 & 133.7 & 100 & 158.9 & 100 & 171.1 & 100 \\
\hline & Timber stock & 9,028 & 100 & $9,141.1$ & 100 & 10,1368 & 100 & $11,2665.9$ & 100 & $12,4558.5$ & 100 \\
\hline & Forest cover & $12.0 \%$ & & $13.0 \%$ & & $13.9 \%$ & & $16.6 \%$ & & $18.2 \%$ & \\
\hline \multirow[t]{3}{*}{ Northeast } & Forested area & 35.1 & 31.0 & 35.7 & 29 & 36.6 & 28 & 39.4 & 25 & 41.3 & 24.5 \\
\hline & Timber stock & $2,941.4$ & 33.4 & $2,892.4$ & 32 & $3,002.7$ & 30 & $3,178.9$ & 29 & $3,293.0$ & 27.2 \\
\hline & Forest cover & $19.5 \%$ & & $19.8 \%$ & & $20.3 \%$ & & $21.9 \%$ & & $22.9 \%$ & \\
\hline \multirow[t]{3}{*}{ Southwest } & Forested area & 22.3 & 19.7 & 26.5 & 22 & 28.1 & 21 & 33.5 & 21 & 37.6 & 22.3 \\
\hline & Timber stock & $3,546.4$ & 40.3 & $3,770.1$ & 42 & $4,464.4$ & 45 & $4,806.0$ & 44 & $5,245.2$ & 43.4 \\
\hline & Forest cover & $10.3 \%$ & & $12.2 \%$ & & $12.9 \%$ & & $15.4 \%$ & & $17.3 \%$ & \\
\hline \multirow[t]{3}{*}{ South } & Forested area & 39.2 & 34.6 & 41.1 & 33 & 46.6 & 35 & 59.0 & 38 & 63.3 & 37.5 \\
\hline & Timber stock & $1,475.8$ & 16.8 & $1,337.5$ & 15 & $1,457.7$ & 15 & $1,794.2$ & 16 & $2,305.5$ & 19.1 \\
\hline & Forest cover & $25.3 \%$ & & $26.5 \%$ & & $30.1 \%$ & & $38.0 \%$ & & $40.8 \%$ & \\
\hline \multirow[t]{3}{*}{ Three-North } & Forested area & 16.6 & 14.7 & 19.4 & 16 & 20.4 & 15 & 25.0 & 16 & 26.7 & 15.8 \\
\hline & Timber stock & 837.6 & 9.5 & 914.3 & 10 & 985.1 & 10 & $1,129.3$ & 10 & $1,254.0$ & 10.4 \\
\hline & Forest cover & $4.1 \%$ & & $4.8 \%$ & & $5.1 \%$ & & $6.2 \%$ & & $6.6 \%$ & \\
\hline
\end{tabular}

Notes: units $=$ million ha $($ area $) /$ million $\mathrm{m}^{3}$ (stock).

1. Forest regions include the following provinces:

Northeast: Heilongjiang, Jilin and Inner Mongolia;

Southwest: Sichuan (Chongqing included), Yunnan and Tibet;

South: Anhui, Zhejiang, Fujian, Jiangxi, Hunan, Hubei, Guangdong, Guangxi, Hainan, and Guizhou;

Three-North: Liaoning, Hebei, Beijing, Tianjin, Shandong, Jiangsu, Shanghai, Shanxi, Henan, Shaanxi, Ningxia, Gansu, Qinghai, and Xinjiang.

2. The first forest inventory was conducted in 1973-1976. At that time, the total forest area was 121.9 million ha with a stock volume of 9532.3 million $\mathrm{m}^{3}$, and the forest cover was $12.7 \%$.

Source: State Forestry Administration, Sixth forest inventory. 
Table 2 - Forest resources by ownership over trees

\begin{tabular}{l|cc|cc|cc}
\hline \multirow{2}{*}{ Categories } & \multicolumn{2}{|c|}{ State forests } & \multicolumn{2}{c|}{ Collective forests } & \multicolumn{2}{c}{ Private forests } \\
& & $\%$ & & $\%$ & & $\%$ \\
\hline Forested area & 72.8 & $42.2 \%$ & 64.8 & $37.5 \%$ & 35.1 & $20.3 \%$ \\
Timber stock volume & $8,414.8$ & $69.6 \%$ & $2,863.5$ & $23.7 \%$ & 819.3 & $6.8 \%$ \\
Closed forest area & 68.8 & $48.2 \%$ & 54.3 & $38.0 \%$ & 19.7 & $13.8 \%$ \\
Economic forest & 1.1 & $5.1 \%$ & 7.1 & $33.1 \%$ & 13.2 & $61.8 \%$ \\
Bamboo & 0.3 & $6.6 \%$ & 2.5 & $51.4 \%$ & 2.0 & $42.0 \%$ \\
Natural forest & 61.3 & $52.9 \%$ & 41.5 & $35.9 \%$ & 12.9 & $11.2 \%$ \\
Man-made forest & 8.9 & $16.7 \%$ & 22.4 & $42.0 \%$ & 22.0 & $41.3 \%$ \\
Pre-forest plantation & 0.8 & $17.4 \%$ & 2.0 & $41.5 \%$ & 2.0 & $41.1 \%$ \\
\hline
\end{tabular}

Notes: units $=$ million ha $\left(\right.$ area $/ /$ million $\mathrm{m}^{3}$ (stock).

Source: State Forestry Administration, Sixth forest inventory. 
Table 3 - Timber production under quota system, 1978-2004

\begin{tabular}{cc||cc}
\hline Year & Production & Year & Production \\
\hline 1978 & 51,623 & 1996 & 67,103 \\
1980 & 53,593 & 1997 & 63,948 \\
1985 & 63,234 & 1998 & 59,662 \\
1990 & 55,710 & 1999 & 52,368 \\
1991 & 58,073 & 2000 & 47,240 \\
1992 & 61,736 & 2001 & 45,520 \\
1993 & 63,922 & 2002 & 44,360 \\
1994 & 66,151 & 2003 & 47,589 \\
1995 & 67,670 & 2004 & 51,973 \\
\hline
\end{tabular}

Notes: unit $=1,000 \mathrm{~m}^{3}$.

Source: China Forestry Statistical Yearbook, various editions. 
Table 4 - Forest resource depletion by age group and by origin

\begin{tabular}{l|cc|cc|cc}
\hline \multirow{2}{*}{ Age group } & \multicolumn{2}{|c|}{ Total } & \multicolumn{2}{c|}{ Natural forests } & \multicolumn{2}{c}{ Man-made forests } \\
& Volume & $\%$ & Volume & $\%$ & Volume & $\%$ \\
\hline Total & 372.4 & 100 & 287.7 & 100 & 84.7 & 100 \\
Young & 62.6 & 16.8 & 46.6 & 16.2 & 16 & 18.9 \\
Middle-aged & 147.3 & 39.6 & 108.6 & 37.8 & 38.7 & 45.6 \\
Near mature & 62.9 & 16.9 & 44.7 & 15.6 & 18.2 & 21.4 \\
Mature & 60.8 & 16.3 & 51 & 17.7 & 9.9 & 11.6 \\
Over-mature & 38.8 & 10.4 & 36.8 & 12.8 & 2 & 2.4 \\
\hline
\end{tabular}

Notes: unit $=$ million $\mathrm{m}^{3}$.

Source: State Forestry Administration, Sixth forest inventory. 
Table 5 - Main China's supplying countries by forest products in 2003

\begin{tabular}{l|l}
\hline Product & Top countries in order of descending volume \\
\hline Log & $\begin{array}{l}\text { Russia (softwood), Malaysia (hardwood), New Zealand, Papua New } \\
\text { Guinea (hardwood), Gabon. } \\
\text { Indonesia (hardwood), USA, Thailand, Russia (softwood), Malaysia } \\
\text { (hardwood). } \\
\text { Lumber }\end{array}$ \\
Panel segment \\
Wood Pulp \\
Caper
\end{tabular}

Source: Sun et al., 2004a. 
Figure 1 - Change in China's forest resources by forest type

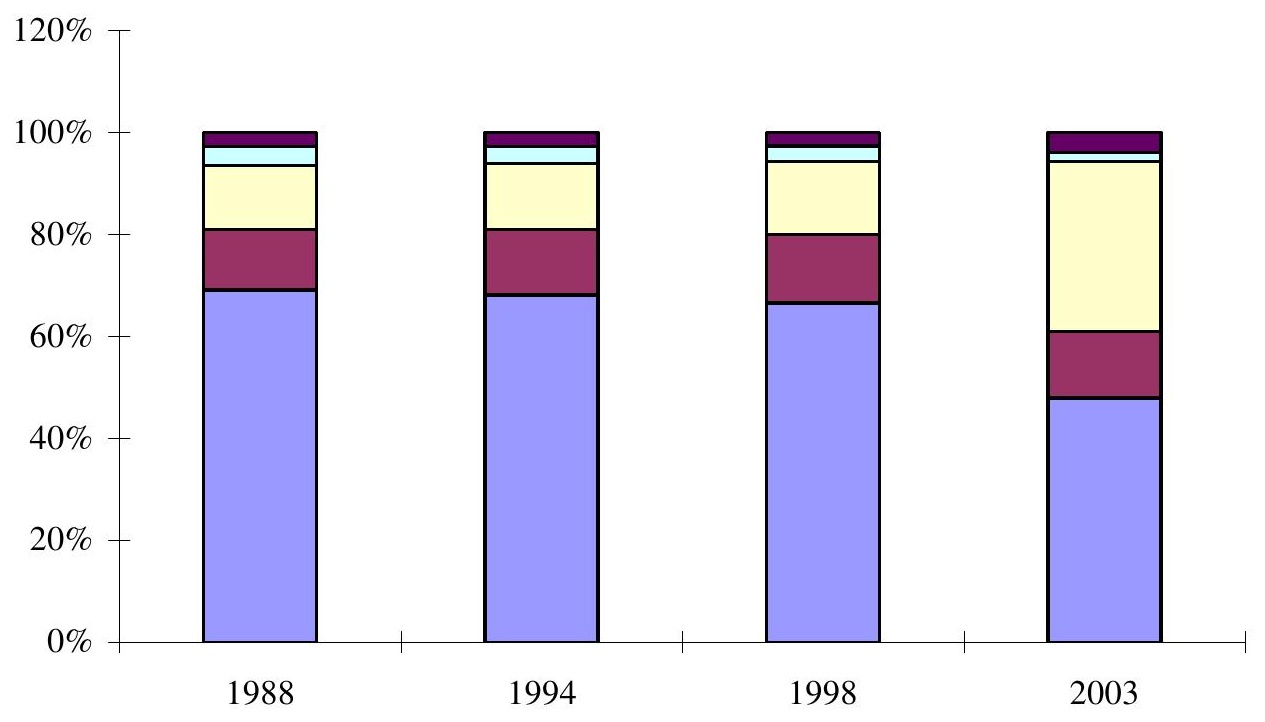

$\square$ Timber $\square$ Economic forest $\square$ Protection $\square$ Fuelwood $\square$ Special use

Notes: years refer to the end of the corresponding $\left(3^{\text {rd }}, 4^{\text {th }}, 5^{\text {th }}\right.$ and $\left.6^{\text {th }}\right)$ national forest inventories. Source: State Forestry Administration, various national forest inventories. 
Figure 2 - Distribution of afforestation by forest type (1991-2004)

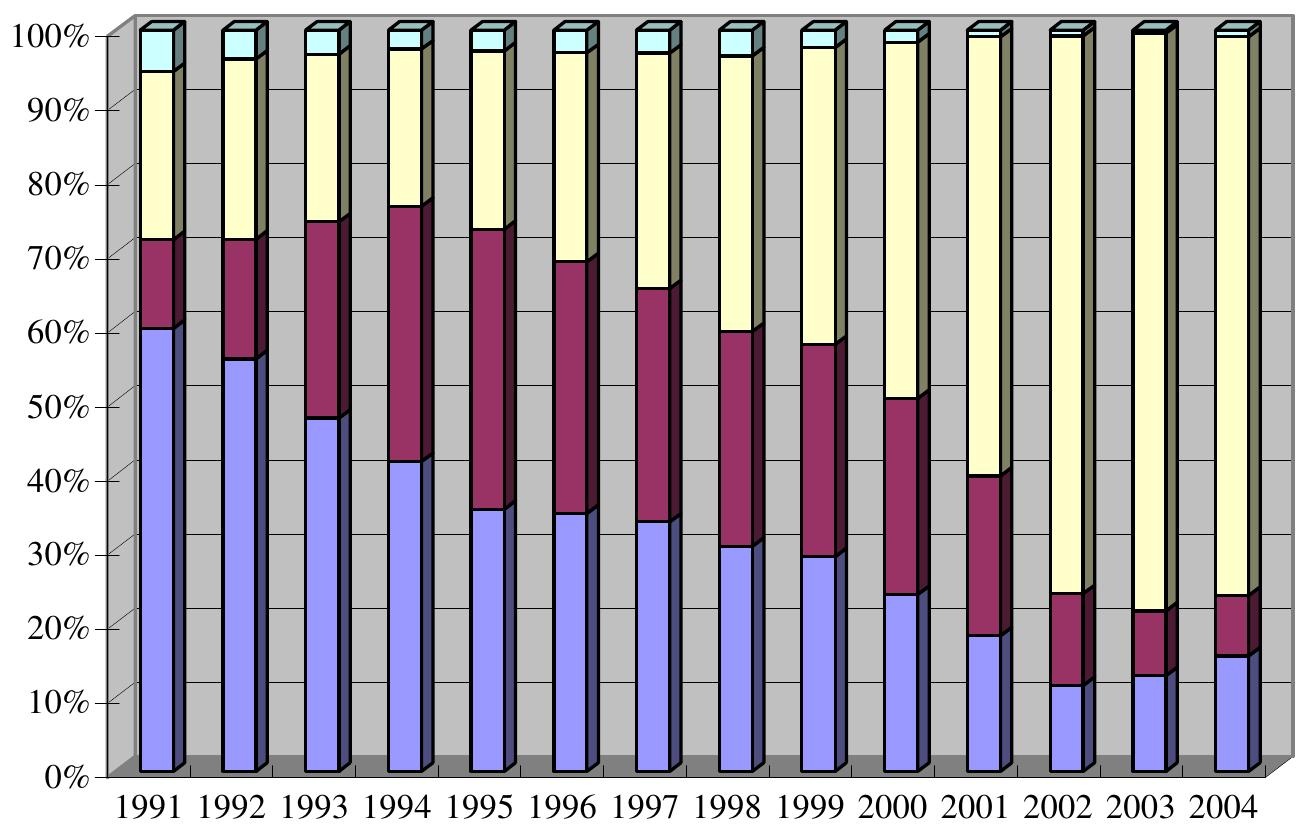

$\square$ Timber $\quad \square$ Economic forest $\quad \square$ Ecological forest $\quad \square$ Fuelwood

Notes: Ecological forest includes protection forest and forest for special use.

Sources: China Forestry Statistical Yearbook (various editions). 
Figure 3 - China's forest resources by age group

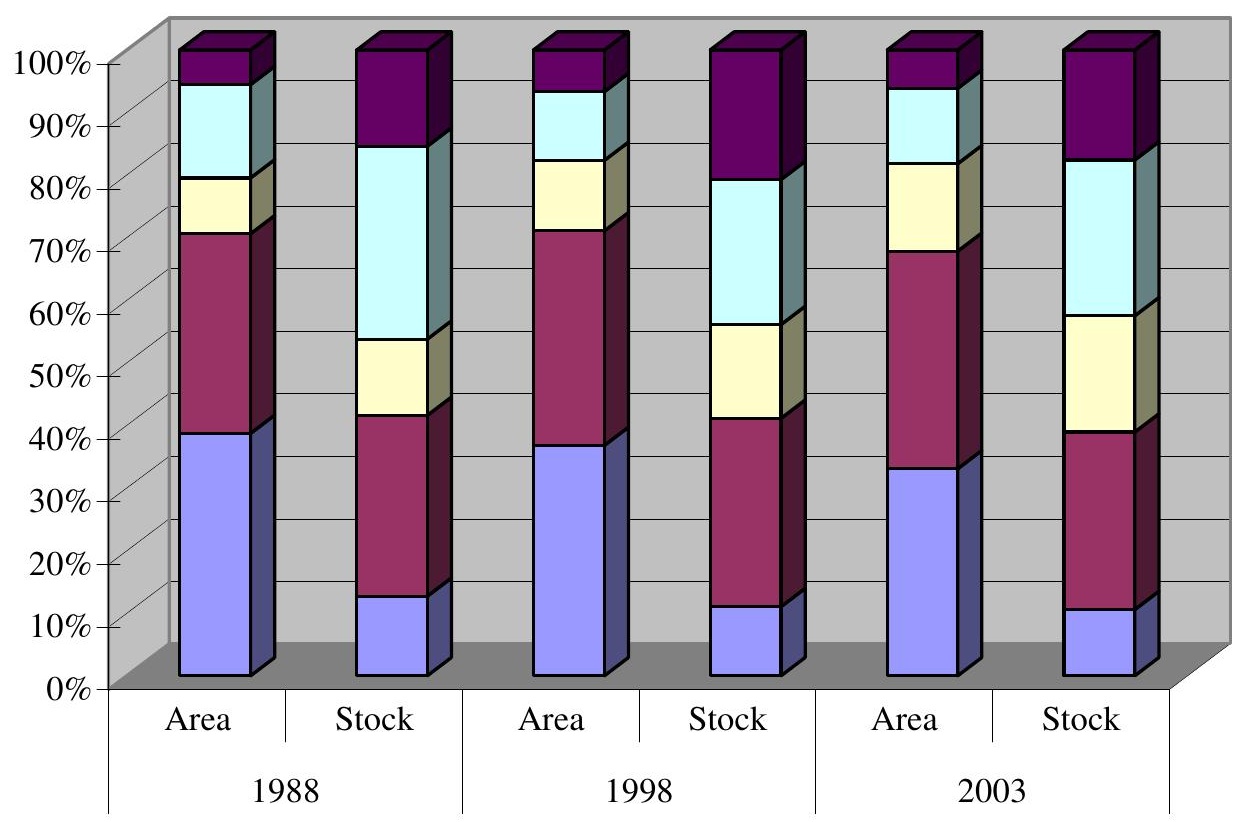

$\square$ Young $\square$ Middle-aged $\square$ Near mature $\square$ Mature $\square$ Over-mature

Notes: years refer to the end of the corresponding $\left(3^{\text {rd }}, 5^{\text {th }}\right.$ and $\left.6^{\text {th }}\right)$ national forest inventories. Source: State Forestry Administration, various national forest inventories. 
Figure 4 - China's import of forest products (1993-2004)

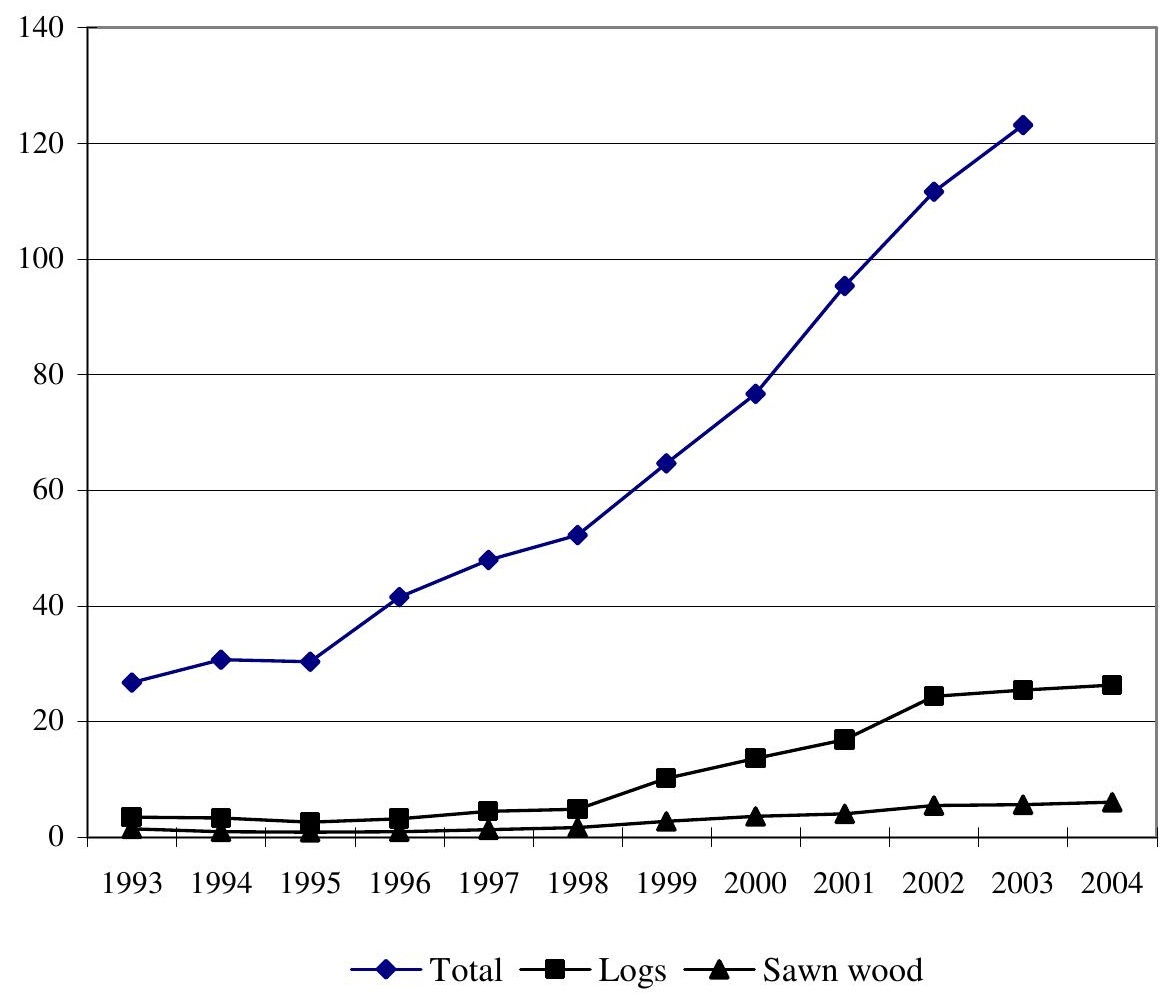

Notes: Total import includes boards, paper, paper pulp and waste paper converted into $\mathrm{m}^{3}$ of round-wood. Unit $=$ million $\mathrm{m}^{3}$.

Sources: Xiong (2004) for total import and China Forestry Statistical Yearbook (2004) for log and sawn wood imports. 